THE PARADOX OF FREEDOM AND AUTONOMY IN NURSES' ACTIONS

Ramone Aparecida Przenyczka1, Maria Helena Lenardt², Verônica de Azevedo Mazza³, Maria Ribeiro Lacerda ${ }^{4}$

${ }^{1}$ Master's student, Graduate Nursing Program, Universidade Federal do Paraná (UFPR). Paraná, Brazil. E-mail: przenyczka@ yahoo.com.br

2 Ph.D. in Nursing Philosophy. Senior Professor, Graduate Nursing Program at UFPR. Paraná, Brazil. E-mail: curitiba.helena@ gmail.com

${ }_{3}^{3}$ Ph.D. in Nursing. Adjunct Professor at UFPR. Paraná, Brazil. E-mail: mazzas@ufpr.br

${ }^{4}$ Ph.D. in Nursing Philosophy. Adjunct Professor at UFPR. Paraná, Brazil. E-mail: lacerda@milenio.com.br

ABSTRACT: Different factors affect nurses' work relations with consequences on their professional freedom/autonomy. This can be understood in different ways, according to philosophical works and also lead to competing conclusions. Considering some of these concepts, this essay was carried out aiming to reflect on nurses' professional freedom/autonomy focusing on some philosophical currents regarding freedom. From the considerations, it can be inferred that nursing freedom/autonomy, protected by Nursing Professionals' Code of Ethics, is correlated to an objective possibility where the professional has action power within an array of faculties (or possibilities) and facing the diversities in his/her work relations still needs to overcome hindrances to achieve his/her ideal of freedom. DESCRIPTORS: Nursing. Professional autonomy. Professional practice.

\title{
O PARADOXO DA LIBERDADE E DA AUTONOMIA NAS AÇÕES DO ENFERMEIRO
}

RESUMO: Diferentes fatores afetam as relações de trabalho do enfermeiro, com consequências sobre sua liberdade/autonomia profissional. Esta pode ser entendida de modos diferentes, conforme as obras de filosofia, e levar a conclusões, também, díspares. Para considerar alguns desses conceitos, realizou-se este ensaio com o objetivo de refletir sobre a liberdade/autonomia profissional do enfermeiro no âmbito de algumas correntes filosóficas sobre a liberdade. Das ponderações feitas, infere-se que a liberdade/autonomia do enfermeiro, protegida pelo Código de Ética dos Profissionais de Enfermagem, corresponde a uma possibilidade objetiva na qual o profissional tem poder de ação dentro de um conjunto de faculdades (ou possibilidades) e que, frente às diversidades que enfrenta nas suas relações de trabalho, ainda precisa vencer certos empecilhos, para atingir seu ideal de liberdade.

DESCRITORES: Enfermagem. Autonomia profissional. Prática profissional.

\section{LA PARADOJA DE LA LIBERTAD Y DE LA AUTONOMÍA EN LAS ACCIONES DE ENFERMEROS}

\begin{abstract}
RESUMEN: Existen diversos factores que afectan las relaciones de trabajo del enfermero con consecuencias para su libertad/autonomía profesional. Esta puede ser entendida de diversas maneras, de acuerdo con las obras de filosofía, y conducen a conclusiones, también, dispares. Para considerar algunos de estos conceptos, se llevó a cabo este ensayo con el fin de reflexionar sobre la libertad y la autonomía profesional del enfermero dentro de algunas corrientes filosóficas sobre la libertad. De las afirmaciones hechas, parece que la libertad/ autonomía del enfermero, protegida por el Código de Ética de los Profesionales de Enfermería, corresponde a una posibilidad objetiva cuando el profesional tiene el poder de actuar en un conjunto de facultades (o posibilidades) y que, de frente a la diversidad en sus relaciones de trabajo, aún tiene que superar ciertos obstáculos para lograr su ideal de libertad.
\end{abstract}

DESCRIPTORES: Enfermería. Autonomía profesional. Práctica profesional. 


\section{INTRODUCTION}

The vertiginous changes in society influence nurses' work relations and entail consequences for their professional freedom/autonomy, a concept many philosophers have studied and which until today implies different understandings.

Freedom is "individuals' possibility to express themselves according to their will, their conscience, their nature", 1:1.175 and considerations about it go back to Aristotle. Autonomy, in turn, is understood as the "ability to govern oneself by one's own means"; $1: 225$ the term was introduced by Kant, according to whom it refers to the independence of will with regard to any desire or object of desire and the ability to act according to one's own law. ${ }^{2}$

According to dictionaries, the meanings of these two words correspond to a given philosophical current, specifically that of unconditional freedom. These two distinct terms have meanings that preserve mutual similarities. Regarding their etymological and historical differences, it can be sustained that freedom is the subject's ability to act autonomously. Thus, professional autonomy will be discussed in this paper as a component of nurses' freedom.

In Nursing, the Ethics Code of Nursing Professionals (CEPE) regulates work relations in Nursing and discusses professional practice with freedom and autonomy. ${ }^{3}$ Although ratified, freedom seems to be hindered by that many legal, administrative, ethical and institutional standards that condition and delimit practice, and that is exactly where the paradox of freedom/autonomy in the context of nurses' work is located.

A study about autonomy and care practice indicated conditions like the following as difficulties nurses experience to exercise that prerogative: lack of knowledge, safety, material and human resources, competences in interpersonal relations with the team and freedom, professional devaluation, paradigms of teaching institutions, employers' hierarchy and bureaucracy, and power. ${ }^{4}$

Another study, which aimed to describe and analyze the social representation of professional autonomy public health nurses construct appointed that this representation shows to be contradictory in the participating subjects' mental and social construction; hence, autonomy is not a consolidated phenomenon in professional practice and depends on professional behavior and (normally innovative) actions in public and private services. $^{5}$
The construction of nurses' professional autonomy is a laborious and ancient task, whose explanations go back to the patriarchal society, in which women were considered beings who were easy to dominate. Care practice was developed without prestige and knowledge on care in the hospital environment belonged to men, who practiced medical hegemony. Thus, the nursing profession appears as subordinate and characterized by heteronomy, that is, by the dominion of actions by laws external to the person. ${ }^{6}$

Based on these assertions, it is important to question the range of nurses' freedom/autonomy in their different work relations. Thus, in this essay, the aim is to reflect on their professional freedom/autonomy in the context of some philosophical currents about freedom.

\section{PHILOSOPHY, FREEDOM AND NURSING}

Different types of freedom exist: of thought, ethical, political, economic and legal. Also, more than one philosophical theory exist to examine it..$^{7-8}$

One of them goes back to Greece, originates in Aristotle and is treated as unconditional freedom. ${ }^{7}$ According to this theory, freedom is opposed to what is externally conditioned (need) and to what happens without choice (contingency). Freedom is considered as the unconditional power of will to determine oneself and without internal and/or external constraints, the agent is totally complete in his/her actions. ${ }^{9}$ As, at that time, citizens exercised freedom in public life, the focus on internal freedom related to the I itself did not exist yet. ${ }^{7}$

Aristotle ignored the subject's interior will, contextualized freedom in the policy of the polis and weighted that a voluntary act is free from external constraints, which does not combine with nurses' practice, which is subject to different external limitations. That is the core of the incompatibility between that great philosopher's thesis and the freedom/autonomy of nurses.

Evidently, the ideas of freedom Aristotle exhibited do not correspond to nurses' current practice (perhaps not even at that time). These professionals are not free to do whatever they want. If this type of human freedom is considered, in which everything is permitted, professional responsibility could not be evoked in view of the harm professionals' actions would cause for other people. Being free includes the assumption of rights, responsibilities and duties. 
The increasing complexity of human relations required the need to elaborate distinct rules to regulate human acts and, if this were not the case, society would become disorganized (if everything were permitted to all disproportionately, the freedom of other people would be violated). Consequently, standards are fundamental to protect subjects against nurses' actions, and also to support professional freedom and autonomy.

As mentioned, due to constant contact with other social subjects, nurses cannot act fully spontaneous in their relations with patients or other professionals, due to the legal limits that determine each person's sphere of competency. Another imposition comes from employers, which set different work norms, sometimes even standards that go against those of the profession. Aristotle's conceptions ignore the current world of relations.

The second conception of freedom to be taken into account is that of determinism, a philosophical doctrine according to which there is a cause for everything that exists. At first, this referred to a scientific determinism that only applied to natural laws but, later, other philosophers, including Auguste Comte, found it valid for human actions and desires. ${ }^{7}$ If decisions are causes, then choices are not free and would be an illusion. Subjects do not actually choose, but a set of circumstances (as causes) chooses for the subjects ${ }^{10}$ and, if conditioning (or determinism) is thus complete, responses to actions or events are merely mechanic; human actions are always determined from the outside to the inside ${ }^{11}$ (like by the social environment) and from the inside to the outside (by desires, motives or character).$^{10}$

This position of freedom does not seem to be the most appropriate either for nurses' actions. If reality were as determinism puts it, there would be no way people could be held accountable for their acts, like in the case of the first concept described earlier. If all actions have their causes and there is no way of acting differently, as subjects have already been determined to act that way, one cannot talk about responsibility.

Within a range of alternatives, one can decide which to choose, as the fact that it is causally determined does not mean that man cannot be the conscious and free cause of his acts. The conscience men are endowed with makes them know the causality that determines them to act consciously, turning into a determining causal factor. ${ }^{10}$

The fact of whether nurses participate or not in an abortion, in cases established by law, depends on their choice. They are not predestined to one single option but have others and, choosing one of them, they are acting freely. There are obviously causes (culture, values etc.) that make nurses choose one option or the other, but which do not take away the free nature of their decisions because they are aware of their possibilities. What stands out here is the nurses' knowledge about their profession and the organization of their work. The more knowledge they have about their possibilities, the more diversified these will be. If nurses know and reflect on the causes (the determinants) that interfere in their profession, they can influence them and change the course of action.

Thus, nurses have freedom, but within a set of faculties and, in this context, the current understanding of nurses' professional freedom/ autonomy is directed at the theory of freedom as an objective possibility.

This third conception affirms that freedom is one among various possible choices, but not among any possible choice, as choices are conditioned by natural, cultural and historical circumstances. Whoever has the power to do something is free to do that. One of the representatives of this conception is Merleau-Ponty. ${ }^{9}$

If freedom is real, if nurses can choose among various possible choices, why do studies demonstrate that many limitations on their practice? Is the freedom mentioned so far perhaps only poetry?

In fact, some restrictions derive from the still biomedical health care model, which limit the expression of freedom and are based on socially constituted power relations among different professional categories. Another issue involved is characteristic of the preponderant economic model, which sometimes does not acknowledge professional ideals. Despite these bottlenecks, the results of actions cannot be considered as a need or contingency. Admitting these impediments is the first step in search of professional freedom/ autonomy. Next, one needs to know how to find gaps to turn the set of "possible choices" into reality, which demands knowledge and perseverance.

Moreover, coping with this problem and other contemporary challenges demands a pedagogical restructuring that guarantees nurses' education with competency to act autonomous and judiciously, so as to guarantee comprehensive high-quality, efficient and problem-solving health care. ${ }^{12}$

It is fundamental to seek and organize professional education that takes into account 
workers' needs, and not just market perspectives. This implies coping with the contradictions and challenges present at this historical moment, with possibilities for transformations, giving the opportunity for good polytechnic education, concerned with the construction of a subject with rights and duties, who builds his/her history, inserted in the labor world, endowed with critical awareness that permits autonomy, instead of mere subservience when relating with the world..$^{13}$

Autonomy is a search, as well presented in a social representations-based qualitative research. According to that study, the core of the representation about the expression autonomy comprises knowledge, conquest and responsibility; the analysis of the representational structures demonstrated a process of conquering professional autonomy. ${ }^{14}$ It should be reminded that human beings are not born autonomously, but gain autonomy through a biopsychosocial development process. ${ }^{15}$

Autonomous persons should have freedom to think, different options to act and convenient alternatives. If there is only one way to solve or accomplish something, the existence of autonomy can hardly be affirmed because this enables each person to act on his/her own when confronted with a range of circumstances. ${ }^{16}$

Nurses' choice among different action possibilities should involve discretion. But their option should always be based on moral values, law and institutional standards (provided that these are neither immoral nor illegal). These restrictions favor the group, the common good and the patient's wellbeing. Freedom rests in the coexistence between private freedom and that of other people.

\section{NURSES' FREEDOM/AUTONOMY IN THE ETHICS CODE OF NURSING PROFESSIONALS}

The theme is first mentioned in the CEPE under "Fundamental principles", establishing that "Nursing Professionals act in health promotion, prevention, recovery and rehabilitation, with autonomy and in line with ethical and legal precepts". ${ }^{3: 81}$

In addition, art. $1^{\circ}$ mentions that it is the right of professionals to "practice Nursing with freedom, autonomy $[\ldots]]^{\prime 3}$. 3:81 This right fits into the context of professional relations and is not always respected in nurses' praxis. Like other principles, those of freedom and autonomy regulate bonds among professionals, patients and health institutions.
Other articles in the same code defend respect for professional autonomy concerning other people's actions. Hence, the limit of freedom is the other person's freedom. That is the case of art. $6^{\circ}$, which presents the following responsibility and duty of nursing "to support its relations on law, prudence, respect, solidarity and diversity of opinions and ideological positions" . $^{3: 81}$

In the relation with other professionals, the CEPE clarifies in art. 36 that it is the right of nursing workers to "participate in multi and interdisciplinary professional practice with responsibility, autonomy and freedom". $3: 82$ This is yet another description of nurses' autonomy/freedom.

It should be reminded that the CEPE does not only apply to nurses, but also to nursing technicians and auxiliaries, whom nurses advise and supervise ${ }^{17}$, making the latter responsible for their actions, who are not endowed with autonomy in their practice, but develop their work interdependently. According to CEPE art. 38, it is the duty of nurses to "assume responsibility for any error committed in their professional activities, independently of having been practiced individually or as a team". ${ }^{3: 82}$

In its art. 44, the CEPE establishes the possibility that nurses, whenever their freedom/autonomy is clipped, to turn to the professional council "when impeded from complying with the present Code, the Law on Professional Practice and the Resolutions and Decisions issued by the Cofen/Coren system". 3:83 This shows that nurses' autonomy/ freedom is guaranteed by laws and resolution, including the possibility of applying penalties when some of them are not complied with.

Brazilian legislation does not rank professions. Excellence exists in all of them, which deserve society's respect and reverence. Arguing greater professional authority for older categories is unacceptable. Today, no professional would be able to deliver comprehensive care alone $\mathrm{e}^{18}$ and, as affirmed, autonomy enables human beings to reflect on the limitations imposed on them, with a view to directing their action in view of existing conditions. ${ }^{19}$

\section{FINAL CONSIDERATIONS}

Based on these considerations, nurses' professional freedom is placed in the philosophical current that perceives freedom as an objective possibility. Nevertheless, this is but an introductory reflection on the theme, with needs further 
research and contributions. The topic demands frequent discussions, as it is directly correlated with changes in society.

There are impediments that overpower nurses' freedom. To conquer them, advances are needed in the relations among professionals from different categories, avoiding one overlapping the others and mutually cooperating as members of a single team, whose final commitment is with patient care.

Professionals with further knowledge will definitely be in an advantageous position to practice their autonomy. And, the more nurses are exposed to the concepts and ideas of other disciplines, like Anthropology, Sociology and Philosophy, the more satisfactorily and rapidly these concepts will certainly be assimilated in nursing practice.

Finally, the distancing between the discourse of freedom/autonomy and its practice still persists, leaving a road ahead to achieve our ideal of freedom.

\section{REFERENCES}

1. Houaiss A, Villar MS. Dicionário Houaiss da língua portuguesa. Rio de Janeiro (RJ): Objetiva; 2009.

2. Abbagnano N. Dicionário de filosofia. São Paulo (SP): Martins Fontes; 2007.

3. Brasil. Resolução Cofen 311 , de 08 de fevereiro de 2007: aprova a reformulação do Código de Ética dos Profissionais de Enfermagem. Diário Oficial da República Federativa do Brasil, 13 fev. 2007. Seção 1, p. 81-83.

4. Jesus MS, Said FA. Autonomia e a prática assistencial do enfermeiro. Cogitare Enferm. 2008 Jul-Set; 13(3):410-21.

5. Gomes AMT, Oliveira DC. Autonomia profissional em um desenho atômico: representações sociais de enfermeiros. Rev Bras Enferm. 2010 Jul-Ago; 63(4):608-15.
6. Bianco MHC. Construção da autonomia do enfermeiro no cotidiano: um estudo etnográfico sob o referencial teórico de Agnes Heller. Bauru (SP): EDUSC; 2000.

7. Aranha MLA, Martins MHP. Temas de filosofia. $3^{\text {a }}$ ed. São Paulo (SP): Moderna; 2005.

8. Aranha MLA, Martins MHP. Temas de filosofia. $2^{a}$ ed. São Paulo (SP): Moderna; 1998.

9. Chauí M. Convite à filosofia. $13^{\mathrm{a}}$ ed. São Paulo (SP): Ática; 2009.

10. Vásquez AS. Ética. 20a ed. Rio de Janeiro (RJ): Civilização Brasileira; 2000.

11. Valls ALM. O que é ética. $9^{a}$ ed. São Paulo (SP): Brasiliense; 1994

12. Silva MG, Fernandes JD, Teixeira GAS, Silva RMO. Processo de formação da(o) enfermeira(o) na contemporaneidade: desafios e perspectivas. Texto Contexto Enferm. 2010 Jan-Mar; 19(1):176-84.

13. Bagnato MHS, Bassinello GAH, Lacaz CPC, Missio L. Ensino médio e educação profissionalizante em enfermagem: algumas reflexões. Rev Esc Enferm USP. 2007; 41(2):279-86.

14. Gomes AMT, Oliveira DC. Espaço autônomo e papel próprio: representações de enfermeiros no contexto do binômio saúde coletiva-hospital. Rev Bras Enferm. 2008 Mar-Abr; 61(2):178-85.

15. Sá LV. Oliveira RA. Autonomia: uma abordagem interdisciplinar. Saúde Ética Justiça. 2007; 12(1/2):514.

16. Araújo AA, Brito AM, Novaes M. Saúde e autonomia: novos conceitos são necessários? Rev. Bioet. 2008; 16(1):117-24.

17. Brasil. Lei $\mathrm{n}^{\circ} 7.498$, de 26 de junho de 1986. Dispõe sobre a regulamentação do exercício da Enfermagem. Diário Oficial da República Federativa do Brasil, DF, 26 jun. 1986. Seção 1.

18. Oguisso T, Schmidt MJ. O exercício da Enfermagem: uma abordagem ético-legal. $3^{\mathrm{a}}$ ed. Rio de Janeiro (RJ): Guanabra Koogan; 2010.

19. Koerich MS, Machado RR, Costa E. Ética e bioética: para dar início à reflexão. Texto Contexto Enferm. 2005 Jan-Mar; 14(1):106-10. 